\title{
Podstawowe zasady międzynarodowej ochrony środowiska morskiego. Wybrane aspekty prawa, doktryny i praktyki
}

\section{Pojęcie i znaczenie: „aksjologii międzynarodowej”, „sprawiedliwości międzynarodowej” i „moralności międzynarodowej", a ochrona środowiska morskiego}

Trafnie wywodzi się, że w aksjologii międzynarodowej, rozumianej w różnych jej aspektach i obszarach zastosowania, należy traktować jako wartość to, co spełnia „normę społeczną w zbiorowościach”, i niekiedy odbiega od „idealnej preferencji idealnego podmiotu”. Wskazuje się też, że „system norm moralnych jako swą podstawę przyjmuje wartość słuszności /..." $/ 2$. Preferowanie wartości jako normy społecznej w zbiorowościach oraz zasady słuszności występuje zwłaszcza w regulacjach nowego prawa morza.

Istnieją też pewne zależności między powszechnym systemem wartości a systemem wartości partykularnych, na przykład europejskich. Do wartości pośrednio oddziałujących na współżycie międzynarodowe, zaliczane są: tzw. dobra idealne jak prawa człowieka, korzystna współpraca międzynarodowa oraz ochrona środowiska naturalnego w otoczeniu człowieka, co mocno zaznaczono w wielu regulacjach prawnomiędzynarodowych, a zwłaszcza w Konwencji NZ o prawie morza z 1982 r.

Wartości „aksjologii międzynarodowej” zostały utrwalone w postaci zasad Karty Narodów Zjednoczonych m.in. takich jak: zasada poszanowania praw człowieka, zasada przyjaznej współpracy i współdziałania, zasada utrzymania sprawiedliwości, poszanowania i wykonywania w dobrej wierze przyjętych zobowiązań, wynikających z traktatów i innych źródeł prawa międzynarodowego. Zasady aksjologii międzynarodowej, występujące w Konwencji NZ o prawie morza przedstawiamy w cz. II. niniejszego opracowania.

Także w prawie międzynarodowym prywatnym, występują specyficzne wartości, jak np. pomyślność gospodarcza i społeczna ludności państw umawiających się lub całej ludzkości. Wartości te są także odpowiednio zaznaczone w nowym prawie morza i w prawie morskim, m.in. w odniesieniu do zachowania, ochrony i użytkowania środowiska naturalnego.

\footnotetext{
J. GILAs, Prawo międzynarodowe, Wydawnictwo COMER, Toruń 1995, s. 35.

2 Tamże.
} 
"Sprawiedliwość międzynarodowa” opiera się na zasadzie równości podmiotów prawa międzynarodowego i jest pojmowana i realizowana jako tzw. wzajemność formalna. Jednak we współczesnym prawie morza, prawie ochrony środowiska oraz w prawie gospodarczym i częściowo także w prawie ochrony własności intelektualnej, odstępuje się niekiedy od tej zasady na rzecz zasady uprzywilejowania. Np. w prawie morza na rzecz: krajów sąsiednich, czy krajów śródlądowych nie mających bezpośredniego dostępu do morza oraz krajów rozwijających się gospodarczo.

Można też zauważyć, iż współcześnie pojęcie i istota sprawiedliwości w prawie międzynarodowym opiera się głównie na konstrukcji sprawiedliwości rozdzielczej, a w nowym prawie morza, tj. w Konwencji NZ z Montego Bay (1982) oraz w tzw. nowym międzynarodowym ładzie gospodarczym - stosuje się, niejako równolegle, zasady: sprawiedliwości rozdzielczej i sprawiedliwości wyrównawczej3

Do elementów należących do porządku międzynarodowego są zaliczane także: moralność międzynarodowa ${ }^{4}$ i słuszność międzynarodowa ${ }^{5}$.

Społeczność międzynarodowa ukształtowała zespół norm moralnych mających charakter powszechny, regionalny lub tylko mających znaczenie w relacjach dwustronnych. Moralność międzynarodowa, jest określana jako zespół imperatywów moralnych, pomocnych w ocenie zachowania uczestników stosunków międzynarodowych w ich relacjach umownych. Odnosi się to m.in. do "sprawiedliwych cen” w prawie międzynarodowym gospodarczym, do ocen tego co słuszne, sprawiedliwe lub niesprawiedliwe. Imperatyw moralny wiąże się np. z obowiązkiem niesienia pomocy państwom w sytuacji klęski żywiołowej (np. tsunami), czy katastrofy ekologicznej zaistniałej na dużą skalę. Działania lub zaniechanie państw w takich sytuacjach podlega ocenie moralnej, a nie prawnej.

Prawo międzynarodowe - i jego dziedziny takie jak prawo morza i prawo ochrony środowiska, odwołują się ogólnie do zasad moralności międzynarodowej lub też bliżej określają imperatyw moralny, zadeklarowany w zawartych umowach międzynarodowych. Tak więc w stosunkach międzynarodowych obowiązuje zarówno prawo międzynarodowe, jak i zasady moralności międzynarodowej - i niekiedy trudno jest oddzielić normy prawnomiędzynarodowe od norm "moralnomiędzynarodowych".

Norma moralna różni się od normy prawnej; norma prawna może być podstawą dla odpowiedniego postępowania prawnego, a norma moralna nie. Norma moralna ma tylko charakter jednostronny, imperatywny tworzący jedynie obowiązki, zaś norma prawna - imperatywno-atrybutywny, tj. ma atrybut domagania się przestrzegania danej normy, z możliwością użycia odpowiednich środków prawnych. Norma moralna może jednak stanowić potencjalną normę prawną.

W prawie międzynarodowym, w tym zwłaszcza prawie morza i prawie ochrony środowiska, zostały inkorporowane normy moralne, takie jak: „dobra wiara”, ochrona życia ludzkiego, rozstrzyganie sporów na zasadzie ex equo et bono (tj. zasady słuszności i sprawiedliwości), czy też zasada słusznej reprezentacji geograficznej w organach określonych instytucji, np. zarządzających Obszarem dna morskiego.

3 Tamże, s. 41.

4 Zob. J. Gilas, Prawo międzynarodowe, op. cit., s. 25-27 oraz J. Bialocerkiewicz, Prawo międzynarodowe publiczne. Zarys wykładu, Olsztyn 2003, s. 42-44.

5 J. Gilas, Prawo międzynarodowe, op. cit., s. 27-29. 
Zasada słuszności międzynarodowej (equity) wyraża się w zastosowaniu aktu sprawiedliwości do konkretnego stanu faktycznego. Odwoływanie się do niej występuje m.in. w prawie morza, $w$ rozstrzyganych przez sądownictwo międzynarodowe sporach związanych np. z rozgraniczeniem wód szelfu kontynentalnego. Zasady słusznościowe zostały m.in. sformułowane w wyroku Międzynarodowego Trybunału Sprawiedliwości (MTS) z 1982 r. dotyczącego szelfu kontynentalnego Tunezji i Libii oraz w wyroku z 1985 r. w sprawie szelfu Libii i Malty.

A Trybunał arbitrażowy w Hadze, w swym orzeczeniu końcowym z 1999 r. dotyczącym sporu delimitacyjnego na Morzu Czerwonym między Erytreą i Republiką Jemenu, odwołał się m.in. do prawa islamu i podstawowych jego wartości w odniesieniu do prawa korzystania z zasobów naturalnych mórz i uprawiania rybołówstwa. Uzasadnił też potrzebę ochrony żywotnych interesów żeglugowych społeczności międzynarodowej w wypadku delimitacji przeprowadzanych bilateralnie oraz także interesów użytkowników mórz oraz zasobów naturalnych tych mórz, m.in. położonych transgranicznie ${ }^{6}$.

Omawiane tu zagadnienia prawne i ich aspekty doktrynalne, znajdują pewne odzwierciedlenie w motywowaniu celów, zamierzeń i form ich realizacji w znaczących obszarach działań społeczności międzynarodowej na rzecz ochrony i zachowania morskiego środowiska naturalnego. Uzyskują one także kształt norm prawnych w określonych regulacjach prawnomiędzynarodowych oraz uchwalanych okresowo zaleceń organizacji międzynarodowych, należących do systemu ONZ. Są też przedmiotem studiów, prezentowanych w bogatej literaturze przedmiotu.

W prezentowanym opracowaniu podejmujemy próbę usystematyzowania zbioru zasad aksjologicznych, etycznych i prawnych, zawartych w Konwencji NZ o prawie morza z 1982 r., odnoszących się głównie do zachowania, ochrony i użytkowania środowiska naturalnego mórz i oceanów. Przedstawiamy też główne problemy ochrony środowiska morskiego objęte regulacjami prawnomiędzynarodowymi oraz wybrane zagadnienia teorii i praktyki ochrony tego środowiska w świetle nowych badań czołowych, zagranicznych ośrodków akademickich.

\section{Zbór podstawowych zasad określonych w Konwencji NZ o prawie morza $z 1982 \mathrm{r}$.}

Zawarte w tej Konwencji zasady, odnoszące się do zachowania, ochrony i użytkowania środowiska morskiego, należy postrzegać w szerszym kontekście jej wielu przesłań generalnych, określonych w preambule. Tworzą one bowiem ogólne tło i ramę założeń prawnych, aksjologicznych i moralnych dla całej Konwencji.

W preambule deklaruje się kolejno, mając na uwadze osiągnięcie celów generalnych Konwencji:

- wzajemne zrozumienie i współpracę podmiotów, które do niej przystąpiły;

- utrzymanie pokoju, sprawiedliwości i postępu dla wszystkich ludów świata;

- pokojowe korzystanie z mórz i oceanów;

- sprawiedliwe i efektywne korzystanie z ich zasobów;

6 Zob. L. ŁukaszuK, Wspótczesne spory i konflikty międzynarodowe dotyczqce obszarów morskich. Wybrane zagadnienia prawne i polityczne, Gdynia 2004, s. 84-87. 
- zachowanie zasobów żywych;

- badanie, ochronę i zachowanie środowiska morskiego;

- ustanowienie słusznego i sprawiedliwego międzynarodowego ładu gospodarczego, uwzględniającego interesy i potrzeby całej ludzkości;

- uznanie Obszaru dna morskiego i jego zasobów jako wspólnego dziedzictwa całej ludzkości, przy założeniu że badania i eksploatację tego Obszaru należy prowadzić dla dobra całej ludzkości;

- rozwój prawa morza - jako służący pokojowi, bezpieczeństwu, współpracy i przyjaznym stosunkom między wszystkimi państwami - zgodnie z zasadami sprawiedliwości i równouprawnienia.

Przesłania te i zasady znalazły kontynuację i rozwinięcie m.in. w przepisach Konwencji odnoszących się do poszczególnych obszarów morskich.

W specjalnym reżimie prawnym wyłącznej strefy ekonomicznej (EEZ) obowiązują następujące zasady:

- prawa suwerenne i jurysdykcja państwa nadbrzeżnego;

- określone prawa i wolności innych państw;

- rozwiązywanie sporów między państwami, gdy dochodzi do sprzeczności interesów - według zasady słuszności i z uwzględnieniem wszelkich okoliczności sprawy;

- uwzględnianie praw państw śródlądowych i państw o niekorzystnym położeniu geograficznym - zgodnie z zasadą słuszności w eksploatowaniu odpowiednich części nadwyżek zasobów żywych w EEZ państwa nadbrzeżnego.

W odniesieniu zaś do szelfu kontynentalnego i morza pełnego przyjęto m.in.:

- zasady wolności morza pełnego;

- zasadę wykorzystywania tego morza wyłącznie dla celów pokojowych;

- zasadę nie zgłaszania roszczeń i poddawania swej suwerenności jakiejkolwiek części tego morza;

- zasadę przestrzegania powszechnie przyjętych międzynarodowych przepisów przez statki państwa bandery;

- obowiązek udzielania pomocy osobom znajdującym się w niebezpieczeństwie na morzu;

- obowiązek współpracy w zwalczaniu piractwa;

- obowiązek współdziałania z innymi państwami na rzecz zachowania zasobów żywych morza pełnego.

Państwa położone nad morzami zamkniętymi lub półzamkniętymi (część IX, art. 122, 123) są obowiązane współpracować ze sobą w wykonywaniu swoich praw i obowiązków na morzu, dążąc - także za pośrednictwem właściwej organizacji regionalnej - do koordynowania działań związanych z: gospodarowaniem żywymi zasobami morza, ich zachowaniem, badaniem i eksploatacją, a także ochroną i zachowaniem środowiska morskiego oraz z polityką badań naukowych własnych i wspólnych na danym obszarze morskim. Dotyczy to. m.in. państw położonych nad Bałtykiem, będącym morzem półzamkniętym.

Państwom śródlądowym, tj. nie posiadającym dostępu do wybrzeża morskiego, zapewniono prawo dostępu do morza i od strony morza oraz wolność tranzytu - bez ceł, podatków i innych opłat (oprócz tych za konkretne usługi) oraz równe traktowanie w portach ich statków, tak jak przysługuje ono innym obcym statkom. (Część X). 
Obszerny zbiór zasad ogólnych rządzących tzw. Obszarem, tj. dnem mórz i oceanów oraz ich podziemiem, znajdujących się poza granicami jurysdykcji państwowej, zawiera Konwencja z 1982 r. w rozdziale 2, części XI. Zasady te to:

- uznanie Obszaru i jego zasobów za „wspólne dziedzictwo ludzkości”;

- zakaz zgłaszania roszczeń lub wykonywania suwerenności lub suwerennych praw nad jakąkolwiek częścią Obszaru oraz zakaz zawłaszczania przez osoby fizyczne i prawne jakiejkolwiek jego części;

- niezbywalność zasobów i minerałów, z wyjątkiem sytuacji i procedur określonych w Konwencji;

- zgodność ogólnego postępowania państw w stosunku do Obszaru z postanowieniami Konwencji, zasadami Karty NZ i innymi normami prawa międzynarodowego, w interesie utrzymania pokoju i bezpieczeństwa oraz popierania współpracy międzynarodowej i wzajemnego zrozumienia;

- obowiązek zapewnienia skutecznego przestrzegania zasad rządzących Obszarem i ponoszenie odpowiedzialności, także solidarnej, za szkodę spowodowaną nieprzestrzeganiem obowiązków wynikających z tych zasad;

- prowadzenie działalności w Obszarze z korzyścią dla ludzkości przez państwa, niezależnie od ich położenia geograficznego, ze szczególnym uwzględnieniem interesów i potrzeb państw rozwijających się i ludów, które nie uzyskały pełnej niepodległości lub innego autonomicznego statusu, uznanego przez $\mathrm{ONZ}^{7}$;

- stosowanie zasady słuszności w podziale finansowych i innych ekonomicznych korzyści uzyskiwanych z działalności w Obszarze;

- wykorzystywanie Obszaru wyłącznie w celach pokojowych;

- uwzględnienie praw i uzasadnionych interesów państw nadbrzeżnych, w tym także ich praw do działań zapobiegawczych i innych związanych z zanieczyszczaniem ich wybrzeży lub zagrożeniem zanieczyszczeniami na skutek zdarzeń wynikających z działalności w Obszarze;

- prowadzenie morskich badań naukowych w Obszarze wyłącznie w celach pokojowych i dla dobra całej ludzkości;

- przekazywanie technologii morskich Przedsiębiorstwu i na rzecz państw rozwijających się „na sprawiedliwych i rozsądnych warunkach”;

- zapewnianie skutecznej ochrony środowiska morskiego przed szkodliwymi następstwami, jakie mogą wyniknąć z działalności w Obszarze, w tym zwłaszcza ochrony i zachowania zasobów naturalnych Obszaru oraz zapobieganie wyrządzaniu szkody florze i faunie środowiska morskiego;

- zapewnianie skutecznej ochrony życia ludzkiego w Obszarze, przez przyjmowanie przez Międzynarodową Organizację Dna Morskiego stosownych zasad, przepisów i procedur, uzupełniających prawo międzynarodowe traktatowe w tym zakresie;

7 Jan Białocerkiewicz w swym podręczniku „Prawo międzynarodowe publiczne. Zarys wykładu”. (Wydawnictwo Uniwersytetu Warmińsko-Mazurskiego, Olsztyn 2003, s. 210) trafnie zauważa: „Bez ryzyka popełnienia większego blędu można przyjąć, że oznacza to sprawiedliwość rozdzielczą w podziale środków ze szczególnym uwzględnieniem interesów i potrzeb krajów rozwijających się i narodów, które nie osiągnęly pełnej niepodległości, (...). 
- odpowiednie koordynowanie działalności w Obszarze i w środowisku morskim w odniesieniu do budowanych tam instalacji i innych form działalności;

- zapewnienie udziału państw rozwijających się oraz państw śródlądowych i tych o niekorzystnym położeniu geograficznym w działalności w Obszarze;

- zapewnienie odpowiedniej ochrony obiektom o charakterze archeologicznym lub historycznym, znalezionym w Obszarze jako „dobru ludzkości”, z uwzględnieniem preferencji dla państw uzasadnionej kulturowo, historycznie lub z tytułu pochodzenia danego obiektu.

W Porozumieniu NZ zawartym w Nowym Jorku w 1994 r. w sprawie implementacji części XI Konwencji NZ o prawie morza z 1982 r. i w dołączonym do niego Aneksie, wyrażono troskę o "globalne środowisko naturalne” oraz kierując się „rynkowym podejściem do gospodarki” wprowadzono istotne zmiany dotyczące zasad finansowania badań i przekazywania technologii związanej z działalnością Przedsiębiorstwa i państw, także rozwijających się, w tzw. Obszarze dna morskiego. Zmiany te ograniczają dotychczasowe preferencje na rzecz krajów rozwijających się w zakresie transferu technologii.

Główne problemy związane z ochroną środowiska morskiego w świetle Konwencji NZ z 1982 r. i innych regulacji prawnych zostały szerzej omówione w części III niniejszego opracowania.

W odniesieniu do morskich badań naukowych wprowadzono w Konwencji z $1982 \mathrm{r}$. m.in. zasadę, że mają być one prowadzone zgodnie z przepisami o ochronie i zachowaniu środowiska morskiego (art. 240/d). A ich głównym celem jest badanie istoty zjawisk i procesów zachodzących w środowisku morskim i ich wzajemnych powiązań (art. 243). Natomiast rozwijanie i przekazywanie technologii morskiej, służącej m.in. także do ochrony i zachowania środowiska morskiego, ma odbywać się „na sprawiedliwych i rozsądnych warunkach” „w oparciu o zasady słuszności, dla dobra wszystkich zainteresowanych stron” (art. 266). Popieranie tworzenia dogodnych warunków dla zawierania umów, kontraktów i innych podobnych układów, służących rozwijaniu i przekazywaniu technologii morskich, ma być realizowane „na słusznych i uzasadnionych warunkach”.(art. 269).

Spory międzynarodowe na morzu, dotyczące także ochrony środowiska powinny być obowiązkowo, wedle postanowień części XV Konwencji z 1982 r., załatwiane środkami pokojowymi, wymienionymi w art. 33 ust. 1 Karty Narodów Zjednoczonych. Wprowadzono m.in.: obowiązek uprzedniej wymiany opinii, stosowanie procedur koncyliacji, a także procedury obowiązkowe, w których zapadają wiążące orzeczenia. Dotyczy to także tzw. środków tymczasowych (art. 290), których zastosowanie może zarządzić sąd lub trybunał arbitrażowy, m.in. „w celu zapobieżenia poważnej szkodzie w środowisku morskim".

W postanowieniach ogólnych Konwencji (część XVI), w art. 300 ponownie podkreślono stosowanie zasady „dobrej wiary”: „Państwa Strony powinny wypełniać w dobrej wierze zobowiązania przyjęte na podstawie niniejszej Konwencji oraz korzystać z praw, jurysdykcji i wolności, uznanych w niniejszej konwencji, w sposób niestanowiący nadużycia prawa”. Przedstawiony tu zbiór zasad przewodnich Konwencji NZ o prawie morza z Montego Bay, potwierdza spostrzeżenia sygnalizowane w części pierwszej niniejszego opracowania, dotyczące znaczenia zawartych w tej Konwencji zasad prawa oraz aksjologii, sprawiedliwości i moralności międzynarodowej dla ochrony środowiska morskiego. Zasady te mogą być użyteczne poznawczo oraz pomocne przy interpretowaniu treści normatyw- 
nych tej konwencji, odnoszących się do problemów zachowania, ochrony i użytkowania zasobów naturalnych środowiska morskiego.

\section{Główne problemy międzynarodowej ochrony środowiska morskiego w świetle regulacji prawnych ${ }^{8}$, doktryny i niektórych doświadczeń z praktyki}

1. Potrzeba prawnomiędzynarodowej regulacji ochrony przyrody i środowiska wynika z jedności ekologicznej świata i jego środowisk: wodnego (morza i oceany zajmują 2/3 powierzchni Planety - i są powiązane ze środowiskiem wodnym, lądowym); lądowego i powłoki gazowej Ziemi (tj. atmosfery).

Specyfika środowiska morskiego, jest związana z jego cechami fizyko-chemicznymi i biologicznymi, a także z uwarunkowaniami jego ochrony - ze względu na międzynarodowy charakter: żeglugi, badań i eksploracji dna morskiego, oraz występowanie antropogenicznych zanieczyszczeń transgranicznych. Stąd też występują tu pewne odrębności, odmienności, w podejmowanych przez społeczność międzynarodową działaniach sozologicznych (ochronnych) i związanych $z$ tym regulacjach prawnomiędzynarodowych, mających także wpływ na regulacje krajowe. Istnieje przeto potrzeba badania relacji wzajemnych: prawa międzynarodowego publicznego, prawa regionalnego i prawa krajowego - także i w tym zakresie przedmiotowym.

Szczególnie groźne może być: naruszanie takich systemów ekologicznych jak rafy koralowe, bardzo wrażliwe na zmiany termiczne i zanieczyszczenia; ginięcie zasobów żywych w morzach, tj. ryb oraz zoo- i fitoplanktonu, dostarczającego Planecie znacznych ilości tlenu.

Podejmowane próby klasyfikacji prawnej ochrony środowiska morskiego przed zanieczyszczeniem obejmują zdarzenia ze względu na: ich źródło pochodzenia - tj. ze statków (okrętów), platform wiertniczych i innych form eksploatacji dna morskiego i jego podglebia; rodzaj substancji, takich jak ropa i jej pochodne oraz inne chemikalia oraz skażenia radioaktywne; zamiar sprawcy, tj. zamierzone zatapianie, płukanie zbiorników oraz niezamierzone działania, powstałe w wyniku katastrof lub awarii.

Prawnomiędzynarodowe zasady ochrony środowiska przed zanieczyszczeniami antropogenicznymi to: zasada ochrony środowiska morskiego przed zanieczyszczeniami - jako obowiązek państw i innych podmiotów, w tym organizacji międzynarodowych międzyrządowych; zasada niedopuszczalności wyrządzania szkody środowisku morskiemu innych państw przez państwo nadbrzeżne, działające w akwenach podlegających jego jurysdykcji; zasada niedopuszczalności zanieczyszczania wód morza pełnego.

8 Zob. J. Ciechanowicz-McLean, Międzyanrodowe prawo ochrony środowiska, Wyd. 2. Wydawnictwo Prawnicze LexisNexis, Warszawa 2001. J. Ciechanowicz, Prawo ochrony środowiska, Wyd. Uniwersytetu Gdańskiego, Gdańsk 1992. L. JAsTrzęBski, Prawo ochrony środowiska w Polsce, PWN, Warszawa 1990. A. LIPIŃsKI, Elementy prawa ochrony środowiska, Zakamycze, Kraków 2000. Z. Bukowski, Prawo międzynarodowe a ochrona środowiska, Toruń 2005. R. Paczulski, Prawo ochrony środowiska, Oficyna Wydawnicza Branta, Bydgoszcz 2000. Zob. także L. ŁukAszuk, Międzynarodowa ochrona środowiska morskiego - główne problemy, system regulacji orazzasady i formy wspólpracy (zarys ogólny), „Studia Ecologice et Bioethicae” 1/2003, s. 249-268. 
Zagadnienia te regulują liczne konwencje powszechne $\mathrm{z}$ lat 1954/1962-1973, konwencje regionalne z lat 1969-1976 oraz kodyfikacja w postaci Konwencji NZ o prawie morza z Montego Bay (1982), która wprowadza obowiązek ochrony środowiska morskiego jako ius cogens. Ponadto, materie sozologiczne uwzględniono także w niektórych traktach dwustronnych w Europie o stosunkach dobrosąsiedzkich, które zawarła m.in. także Polska9

W Konwencji NZ o prawie morza z 1982 r. wprowadzono nowe, istotne postanowienia ochronne, w których zawarto: obowiązek ochrony środowiska morskiego - jako podstawowy obowiązek państw; szeroko ujętą definicję zanieczyszczenia środowiska morskiego (art. l pkt. 4), jednak z wyłączeniem estuariów; definicje rodzajów działań zanieczyszczających.

Konwencja ta dotyczy wszystkich obszarów morskich, przy czym: wyeksponowano źródła zanieczyszczenia lądowego; rozszerzono szczególne prawa w zakresie działań ochronnych państwa nadbrzeżnego (art. 21); określono 12 rodzajów działań związanych z przepływem statków (art. 19); uregulowano sytuacje: w cieśninach (art. 39); w wyłącznej strefie ekonomicznej (EEZ); na szelfie kontynentalnym (art. 79); na morzu pełnym (art. 94); w Obszarze dna morskiego poza granicami jurysdykcji państw, uwzględniając rolę Organizacji Dna Morskiego (art. 145) i przyjęte przez nią zasady.

W Konwencji NZ o prawie morza zaakcentowano odpowiednio zagadnienia technologii w kontekście ochrony i zachowania środowiska morskiego. I tak:

- W art. 196 ust. 1 Konwencji z 1982 r. postanowiono, iż: „Państwa stosują wszelkie środki konieczne do zapobiegania, zmniejszania i kontroli zanieczyszczenia środowiska morskiego w następstwie powstałego stosowania technologii na obszarach będących pod ich jurysdykcją lub kontrolą, albo powstałego umyślnego lub przypadkowego wprowadzenia obcych lub nowych gatunków do określonej części środowiska morskiego, które może spowodować w nim znaczne i szkodliwe zmiany".

- W art. 202 i 203 przewidziano pomoc naukowąi techniczną dla państw rozwijających się oraz uprzywilejowane traktowanie tych państw - w celu ochrony i zachowania środowiska morskiego oraz zapobiegania, zmniejszania i kontroli zanieczyszczania środowiska morskiego. Państwa bezpośrednio lub za pośrednictwem właściwych organizacji międzynarodowych mają udzielać pomocy m.in. w: szkoleniu ich personelu naukowego i technicznego; dostarczaniu im niezbędnego wyposażenia i urządzeń; zwiększaniu ich zdatności do wytwarzania takiego wyposażenia; przydziale odpowiednich funduszy i pomocy technicznej (art. 203) a to wszystko niewątpliwie wiąże się także $\mathrm{z}$ rozwojem i transferem odpowiednich technologii.

Z przepisów części XII Konwencji NZ z 1982 r., dotyczącej ochrony środowiska morskiego, można wyprowadzić cztery główne zasady. Są to: a) zasada ogólna ochrony środowiska morskiego (art. 192); b) zasada współpracy państw w tym zakresie (art. 194), w związku $\mathrm{z}$ art. 207 ust. 4, gdzie nadano dużą rangę współpracy regionalnej. Na państwa nałożono obowiązek: notyfikacji o grożącej lub faktycznej szkodzie ekologicznej (art. 198), stworzenia systemu informacji o jakości środowiska i jego zagrożeniu, ustalenia ogólnie obowią-

9 Zob. J. KukuŁKa, Traktaty sasiedzkie Polski odrodzonej, Ossolineum, 1998; Traktaty o przyjaźni i współpracy zawarte przez Polskę. Wybór dokumentów. Wstęp i opracowanie Anna Przyborowska-Klimczak, Wojciech Szczepan Staszewski, Lubelskie Wydawnictwo Prawnicze, Lublin 2005. 
zujących norm określających maksymalny poziom dopuszczalnego zanieczyszczenia mórz, udzielania pomocy państwom rozwijającym się w postaci funduszy, pomocy fachowej, korzystania ze służb specjalistycznych; c) zasada „samoobrony”, tj. prawo podejmowania niezbędnych środków zapobiegających (art. 207-212); d) zasada odpowiedzialności państw za zanieczyszczanie środowiska morskiego (Część XII, rozdz. 9) tj. za nieprzestrzeganie przepisów ochronnych; odpowiedzialność karna, pieniężna (art. 230). Odpowiedzialność ta została oparta na przesłankach obiektywnych (art. $235 \$ 2$ ).

Odpowiedzialność za zanieczyszczenia środowiska morskiego, wynikająca z zasady „polluter pays” (zanieczyszczający płaci) została uznana przez OECD, Wspólnoty Europejskie i Radę Europy.

System odszkodowań za tzw. szkody olejowe - po katastrofie „Torrey Canzon” kształtują dwie główne regulacje prawnomiędzynarodowe: Konwencja o utworzeniu Międzynarodowego Funduszu Odszkodowań za Szkody Spowodowane Zanieczyszczeniami Olejowymi, sporządzona w Brukseli 18 XII 1971 r. (ratyfikowana 1985 r.); Protokół do Międzynarodowej Konwencji od Odpowiedzialności Cywilnej za Szkody Spowodowane Zanieczyszczeniami olejowymi sporządzony w Londynie 19 XI 1976 r. (ratyfikowany w 1985 r.). Polska należy do tych konwencji. Polski Kodeks morski w tyt. VIII przewiduje odpowiedzialność za szkodę za zanieczyszczenie środowiska morskiego.

W prawie Wspólnot i Unii Europejskiej (wtórnym) tj. w dyrektywach i decyzjach przewidziano ochronę środowiska i odpowiedzialność za zanieczyszczenia. Państwa UE są stroną umów powszechnych i regionalnych, a głównie MARPOL 73/78; dotyczących Morza Bałtyckiego z 1974 i 1992 r. oraz Konwencji NZ o prawie morza z 1982 r.

2. A to co wynika z praktyki państw stosujących Konwencję NZ z $1982 \mathrm{r}$. w tym zakresie w latach 1982-2000 w EEZ przedstawiono m.in. w niektórych publikacjach ${ }^{10}$. Dotyczy to głównie zanieczyszczeń pochodzących ze statków z perspektywy państw nadbrzeżnych, np. Belgii, w relacji do Morza Północnego, z uwzględnieniem zagadnień zachowania i ochrony środowiska morskiego.

W odniesieniu do ochrony środowiska morskiego w EEZ w publikacji tej wskazuje się także na rolę International Law Association - ILA w stopniowym rozwoju prawa międzynarodowego, tj. Komitetu (Komisji) ILA ds. Zanieczyszczeń morskich, także w kontekście zanieczyszczeń pochodzących ze statków ${ }^{11}$.

Postanowienia konferencji legislacyjnej ILA dotyczyły głównie: kwestii uprawnień państw do egzekwowania prawa w EEZ oraz w obszarach (strefach) specjalnych EEZ (art. 211/6/ Konwencji z 1982 r.), tj. wyraźnie oznaczonych obszarach w tej strefie z powodu uznanych przyczyn technicznych, oceanograficznych i ekologicznych oraz ze względu na sposób wykorzystania tego obszaru lub ochronę jego zasobów i szczególny charakter żeglugi po nim - wymagane jest przyjęcie specjalnych środków posiadających moc wiążącą, w celu zapobiegania zanieczyszczeniom ze statków. Państwa nadbrzeżne mogą,

\footnotetext{
10 E. Franckx, P. Gautier/eds./, The Exclusive Economic Zone and the United Nations Convention on the Law of the Sea, 1982-2000. A Preliminary Assessment of State Practice, Bruylant, Bruksela 2003.

11 Tamże.
} 
po konsultacjach prowadzonych za pośrednictwem właściwej organizacji międzynarodowej z innymi zainteresowanymi państwami, skierować do tej organizacji zawiadomienie dotyczące takiego obszaru, oparte na świadectwach naukowych i technicznych, a także informację o odpowiednich urządzeniach przyjmujących. Podejmowanie działań implementacyjnych przez państwa nadbrzeżne w obszarach EEZ pokrytych lodem (art. 234), upoważnia te państwa do wydawania przepisów prawnych proekologicznych, a także w kontekście zagrożeń dla żeglugi morskiej.

Polityka ekologiczna jest współcześnie analizowana w kontekście tzw. ewolucyjnej ekonomiki oraz wymogów zrównoważonego rozwoju ${ }^{12}$. Polityka taka, prowadzona przez państwa, wywiera wpływ na gospodarkę, jej ewolucję. Pomaga też kreować i rozwijać w praktyce specjalne technologie energetyczne, takie np. jak energia nuklearna i energia elektryczna czerpana ze światła słonecznego.

Prawo ochrony środowiska przechodzi kolejne fazy rozwoju, o czym świadczą m.in. doświadczenia uzyskane w Indonezji, dużym państwie wyspiarskim, archipelagowym, należącym do grona państw rozwijających się. Ochrona środowiska jest tam przeto ściśle związana z użytkowaniem licznych akwenów morskich. Problemem w Indonezji, podobnie jak i w innych krajach rozwijających się, jest mała zdolność implementowania nowych idei i rozwiązań proekologicznych, zaczerpniętych z krajów wysokorozwiniętych. Chodzi tu zwłaszcza o odpowiednie zintegrowanie prawa ochrony środowiska i stosowanie zorientowanych rynkowo instrumentów konsekwentnego, skutecznego stosowania tego prawa. Prawo ochrony środowiska jest bowiem dobrze rozwinięte modelowo, teoretycznie, ale w praktyce jego stosowania napotyka na trudności związane z odpowiednim monitorowaniem i adekwatnym egzekwowaniem jego zasad i norm. Zjawisko takie występuje m.in. w Indonezji ${ }^{13}$.

Akwakuturze - jako „uprawie morza”, oraz ochronie środowiska mogą służý morskie badania naukowe, prowadzone ostatnio bardziej skutecznie, dzięki wykorzystywaniu nowych technik elektronicznych. Dzięki Internetowi, możliwe jest np. przekazywanie wizualnie, występującego regularnie, w skali masowej, w wodach raf koralowych u brzegów Tajwanu zjawiska owulacji koralowców ${ }^{14}$.

Projekt podwodnego monitoringu został podjęty wspólnie przez: the Research Center for Biodiversity of Academia Sinica, the National Center for High Performance Computing (NCAC), the National Museum of Marine Biology and Aquarium i the Third Nuclear Power Plant of Taiwan Power Company.

Program badań posługuje się zestawem dziewięciu kamer i innego wyposażenia, umieszczonego na głębokości 7-8 m w wodach zatoki, w pobliżu elektrowni jądrowej pracującej w sąsiedztwie Kenting National Park, na południowym cyplu wyspy, gdzie wody przybrzeżne charakteryzują się największą różnorodnością koralowców z tych występujących na Tajwanie, bowiem obejmują ponad 350 ich gatunków. Poza tym obszar ten oceniany

12 Jeroen C.J.M. van den Bergh i in. Evolutionary Economics and Environmental Policy. Survival of the Greenest, Edward Elgar Publishing, Cheltenham 2007.

13 M. Faure, N. Niessen, Environmental Law in Development. Lessons from the Indonesian Experience, Edward Elgar Publishing, Cheltenham 2006.

14 Zob. Owen Chu, Sea ecology studied using new technique, „Tajwan Journal”, November 12, 2004, s. 8 . 
jest jako nieskażony działalnością ludzi, a wody zatoki są osłaniane falochronem przed skutkami cyklonów.

Oczekuje się, że badania te pozwolą określić przyczyny niszczenia raf koralowych w tym obszarze, takimi czynnikami jak: cykle zmian klimatycznych typu El Niňo, czy też nielegalne rybołówstwo i zanieczyszczenia.

Umieszczone na przymocowanej trwale stalowymi belkami do skalistego podłoża platformie urządzenia badawcze podzielono na trzy specjalistyczne grupy instrumentów, uwzględniając uwrażliwienie organizmów morskich na obce źródła światła.

Zainicjowany przez ekologów Tajwanu projekt badań rafy koralowej, z zastosowaniem nowoczesnego systemu obserwacji podwodnej, jest pierwszym, unikalnym takim rozwiązaniem w świecie. The Australian Institute of Marine Science oraz University of California w Santa Barbara zwróciły się do tajwańskiego zespołu badawczego o konsultacje techniczne do realizowanych oddzielnie przez te ośrodki naukowe programów obserwowania koralowców w obszarach: the Great Barrier Reef w Australii oraz na Wyspie Moorea na Południowym Pacyfiku.

Trudności techniczne jakie pokonano w badaniach rafy koralowej na Tajwanie to: zabezpieczenie źródeł zasilania aparatury, ochrona urządzeń przed korozją oraz ochrona kamer przed efektem ich „zamglenia”, powodowanego różnicą temperatur wody morskiej i kamery. Głównym wyzwaniem w tych badaniach jest nadal odpowiednie zintegrowanie wielu różnych procesów, związanych $\mathrm{z}$ wykonywaniem zdjęć podwodnych.

Realizowany na Tajwanie projekt badawczy, związany z obserwowaniem koralowców, jest częścią ekologicznego programu badawczego wód przybrzeżnych w obszarze Nanwan, należącym do Kenting National Park. Realizowany program jest częścią ogólnokrajowego projektu wdrożonego w $1992 \mathrm{r}$. przez National Science Council Tajwanu. Inne studia są prowadzone przez trzy mniejsze prowincjonalne rezerwaty przyrody. Związane z tym różne problemy techniczne, dotyczą m.in. zróżnicowanego czasu użytkowania pod wodą sprzętu elektronicznego i sprzętu mechanicznego.

Użytkowanie sieci urządzeń badawczych projektu do obserwacji raf koralowych jest obecnie dostępne jedynie dla instytutów uniwersyteckich i naukowo-badawczych. Ale nowe techniki obserwacji podwodnych mogą mieć wielorakie zastosowanie.

Według oceny Research Center for Biodiversity, obecnie działający system może być wykorzystywany do: weryfikowania skutków działania raf sztucznie tworzonych przez czlowieka dla osiągania rozwoju populacji ryb (tj. w akwakulturze); badania stale odkrywanych nowych rodzajów organizmów morskich oraz do prowadzenia nadzoru nad rezerwami zasobów morskich, czy też do nadzorowania stref wojskowych dla celów bezpieczeństwa.

Oprócz monitorowania koralowców, projekt realizowany w Kenting ma na celu obserwowanie zachowania się fauny morskiej oraz całego ekosystemu morskiego w dłuższym okresie, np. dwuletnim. Podobne projekty badań podwodnych mają być wdrażane lokalnie u wybrzeży innych wysp, takich jak Wyspy Pratas. Według oceny Petera Arzbergera, dyrektora National Biomedical Computation Resources z Uniwersytetu Kalifornii w San Diego, realizowany na Tajwanie system monitoringu podmorskiego może odegrać wiodącą rolę w ochronie koralowców w skali światowej.

Przedmiotem stałej troski są wciąż zjawiska związane z procesami zmian klimatu Planety. Znajduje to m.in. wyraz w analitycznej interpretacji i syntezie informacji na- 
ukowych i technicznych, połączonych z modelowaniem tych zjawisk, a także w prowadzonych na wysokim poziomie analizach normatywnych. Towarzyszy temu pogłębiona refleksja teoretyczna dotycząca problemów etycznych współczesności. Wskazuje się na potrzebę stosowania w praktyce ochrony środowiska, właśnie norm etycznych ${ }^{15}$.

W etycznym, aksjologicznym i prakseologicznym podejściu do problemów ochrony środowiska mają znaczenie: zasada przezorności (precautionary principle) oraz zasada strategicznej oceny środowiska (strategic environmental assessment). Wskazują one jak osiągać lepsze wyniki (skutki) podejmowanych decyzji, zwłaszcza w samym procesie ich podejmowania. Dotyczy to także procesów tworzenia i stosowania prawa ochrony środowiska w odniesieniu do środowiska morskiego.

Zasada przezorności odgrywa dużą rolę w przypadku ryzyka związanego z zarządzaniem, jak i z oceną skali samego ryzyka. Ryzyko dotyczy zwłaszcza takich dziedzin jak: stosowanie nanotechnologii, zmian klimatu, zarządzania zasobami naturalnymi oraz polityka $\mathrm{w}$ dziedzinie zdrowia publicznego. Konieczne są tu spójne interdyscyplinarne analizy, odwołujące się do perspektyw wywodzących się z nauk prawnych, nauk społecznych oraz do polityki społecznej - z postrzeganiem potrzeb demokratycznej legitymizacji i efektywności polityki w sferze publicznej, zarówno w skali międzynarodowej, jak i na poziomie państw ${ }^{16}$.

Dyrektywa unii Europejskiej o strategicznej ocenie środowiska wymaga wprowadzenia w życie przepisów prawa i określonych wskazówek praktycznych w każdym państwie członkowskim.

Procedury związane ze strategiczną oceną środowiska są bowiem już stosowane w innych państwach świata. Chodzi tu o analityczne podejście do tego zagadnienia oraz o jakość podejmowanych działań, tak aby zapewnić pełne zintegrowanie wartości związanych $\mathrm{z}$ ochroną środowiska $\mathrm{z}$ procesami podejmowania decyzji ${ }^{17}$.

Prawo ochrony środowiska jest nadal przedmiotem rosnącego zainteresowania badawczego. Wzajemne powiązanie różnymi sieciami informacji społeczeństwo globalne, poczyniło już wiele kroków ku kształtowaniu „demokracji środowiskowej” (tj. tej zorientowanej proekologicznie) w procesach podejmowania decyzji. Ale nadal istnieją grupy społeczne, które nie zostały objęte procesami tworzenia prawa ochrony środowiska. Cykl wydawniczy, który od 2006 r. redagują: Kurt Deketelaere i Zen Makuch w oficynie Edward Elgar Publishing, Cheltenham, obejmuje wyniki innowacyjnych badań standardów ochronnych, procedur, alternatywnych instrumentów i konkretnych przypadków $\mathrm{z}$ praktyki stosowania prawa. Konieczna jest bowiem w miarę szeroka interpretacja tego prawa.

15 M. FaUre, G. SKogh, The Economic Analysis on Environmental Policy and Law. An Introduction. Edward Elgar Publishing, Cheltenham, 2006.

16 Zob. E. Fisher, J. Jones, R. von Schomberg (eds.), Implementing the Precautionary Principle. Perspectives and Prospects, Edward Elgar Publishing, Cheltenham, 2006.

17 P. Caratti, H. Dalkmann, R. Jiliberto /eds./, Analysing Strategic Environmental Assessment. Towards Better Decision-Making. Edward Elgar Publishing, Cheltenham, 2004. 


\section{Refleksje ogólne}

Zagadnienia ochrony środowiska morskiego, związane głównie z naukami przyrodniczymi, są od niedawna łączone także z naukami społecznymi i ich systemem wartości oraz regulacjami prawnymi. Humanizacja tych zagadnień wiąże się z tezą, iż każda jednostka ludzka ma prawo do życia w odpowiednim środowisku naturalnym i do jego ochrony. Stale rozszerzające się międzynarodowe regulacje prawne objęły wiele dziedzin ochrony środowiska morskiego i także zalicza się je do zagadnień związanych z prawem człowieka do środowiska, określanym mianem praw człowieka III generacji.

I jakkolwiek tworzone dotychczas zasady i normy prawa międzynarodowego nie mogą sprostać zwłaszcza nowym wyzwaniom związanym z ochroną środowiska morskiego przed wieloma zagrożeniami cywilizacyjnymi, to jednak w znacznej mierze - także dzięki działaniu organizacji międzynarodowych, przyczyniły się do wzajemnego uznania zasad i poszanowania praw i obowiązków państw w działaniach na rzecz zrównoważonego rozwoju cywilizacyjnego. Szczególne znaczenie miały tu inicjatywy i działania ONZ. W wyniku ustaleń konferencji NZ w Rio de Janeiro (1992) uwypuklono znaczenie zależności między ochroną środowiska a rozwojem społecznym i gospodarczym. W podjętej wówczas deklaracji dokonano syntezy zasad kształtującej się ekofilozofii, dobrze kojarzącej różne przejawy ludzkiej działalności z wymogiem jej dbałości o środowisko naturalne. Proklamowano jako cel ustanowienie nowego i sprawiedliwego partnerstwa i nowych form współpracy państw na rzecz ochrony środowiska. Wpłynęło to na wprowadzenie zmian instytucjonalnych i programowych w działalności właściwych organizacji międzynarodowych.

Zasady dotyczące ochrony środowiska, także morskiego, są jako zasady ogólne, wspólne systemom doktrynalnym i prawnym wielu państw współczesnych, akceptujących powszechnie uznane wartości, utrwalone także w prawie międzynarodowym.

Podjęta w prezentowanym opracowaniu, próba zrekonstruowania zbioru zasad odnoszących się do ochrony środowiska morskiego, wskazuje, iż we współczesnym systemie regulacji prawnomiędzynarodowych, a także tych $z$ obszaru soft law, brak jest jednolitego, odpowiednio spójnego wewnętrznie, „katalogu” zasad prawnych i doktrynalnych.

Dające się wyodrębnić, najczęściej powoływane generalne zasady, odnoszące się także do ochrony środowiska morskiego, to przede wszystkim zasady: troski o wspólne dziedzictwo ludzkości; sprawiedliwości i solidarności - także tej międzypokoleniowej; zrównoważonego rozwoju; udziału publicznego społeczeństw w egzekwowaniu, m.in. poprzez jawność informacji o stanie środowiska, przestrzegania standardów jego ochrony; prewencji; przezorności; nie wyrządzania szkód poza granicami własnego państwa i odpowiedzialności odszkodowawczej - chociaż powszechnej, ale zróżnicowanej. Zasada zrównoważonego rozwoju, powstała na gruncie prawa międzynarodowego, stanowi obecnie jedną z zasad ogólnych tego prawa.

Ochrona środowiska naturalnego, w tym także morskiego, nabiera znaczenia etycznego, a również egzystencjalnego. Dlatego tė̇, począwszy od Konferencji Sztokholmskiej ONZ (1972) ochrona ta zyskała rangę trwałej wartości i została uznana za jedną z podstawowych funkcji każdego współczesnego państwa, integralnie związaną z polityką ochrony środowiska, także w relacjach zewnętrznych. Ma to istotne znaczenie dla uczestniczenia państw w globalnej i regionalnych strategiach ochrony środowiska naturalnego, 
inicjowanych i realizowanych przez społeczność międzynarodową, także na morzach i oceanach.

\title{
Basic principles of international protection of the marine environment: Selected aspects of law, doctrine and policy
}

\author{
SUMMARY
}

Author of this article presents notion and meaning of international protection of the marine environment, and offers a solid legal and philosophical background to this issue.

He points at and systematically analyzes a kind of compendium of selected maine legal and philosophical principles as environmental values, included in the United Nations Convention on the law of the sea (1982). The author discusses both environmental management at seas as a global system and topical issues in the light of international legal instruments, doctrine and some practical experiences. He also shows the environmental law as an increasingly important area of new interdisciplinary study and addresses how this law and science may best able to address the key issues facing the marine environment in the $21^{\text {st }}$ century.

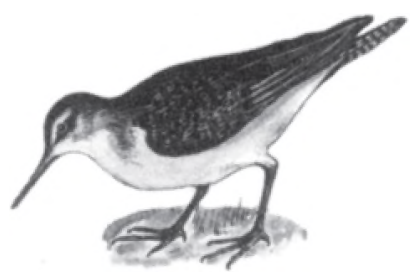

Kuliczek piskliwy 